\title{
Institutional and Strategic Barriers to Public-Private Partnership: An Analysis of Dutch Cases
}

\author{
Erik-Hans Klijn and Geert R. Teisman
}

Public-Private Partnerships (PPPS) are becoming popular in Europe, but does the reality match the idea of co-operating actors who achieve added value together and share risks? An analysis of three PPPs in the Netherlands suggests that, in practice, PPPs are less ideal than the idea. Partners have difficulty with joint decision-making and organization and tend to revert to traditional forms-by contracting out and by separating responsibilities.

The Problem of Co-operation

For the past two decades, a large number of countries have been investigating and promoting Public-Private Partnerships (PPPs). The Dutch Knowledge Centre on PPP, set up in the late 1990 s by the Dutch Ministry of Finance, has stated that 'International experiences demonstrate that a faster and more efficient implementation of infrastructure projects is possible through public-private partnership (PPP). Both public and private actors in the Netherlands have displayed an interest and willingness for PPP' (Kenniscentrum, 1998).

PPPs can be defined as 'co-operation between public and private actors with a durable character in which actors develop mutual products and/or services and in which risk, costs, and benefits are shared'. These are based on mutual added value. Actors foresee additional benefits and expect that these will outweigh the (extra) cost of co-operation.

\section{BAM Conference Prize}

The Public Management and Policy Association and Public Money \& Management awarded a prize for the best academic paper submitted on a public sector theme to the British Academy of Management Conference in September 2002. All eligible papers were refereed, and then discussed by the public management 'track' at the conference. The final decision was made by the chairs of the public management and publicprivate partnerships tracks, who were Francis Terry and Richard Kerley. This article is an abridged version of the prize-winning paper.
Benefits can take a variety of forms, for example financial/material (profits, working space, and increased transport capacity), or more intangibly (image and knowledge development). The costs of co-operation can be one-time only (preparation, adaptation of the internal organization), or recurring (organizational co-ordination, adaptation and tuning of substantive objectives). But what is important is the added value of synergy, i.e. being able to develop a product with characteristics that would not have been available without a PPP.

Co-operation, however, implies an increase in the number of participants. Also, in partnerships, the actors are usually dependent upon each other. These two basic conditions create problems (see, for example, Emerson, 1962; Scharpf, 1978; Rogers and Whetten, 1992; Klijn and Teisman, 2000).

\section{Network Governance}

This problem of co-operation can be explored through the network perspective on governance, which assumes that policy is developed and implemented in networks of organizations (see, for example, Kickert et al., 1997; Klijn and Koppenjan, 2000). Policy networks can be defined as "changing patterns of social relationships between interdependent actors which take shape around policy problems and/or clusters of resources and that are formed, maintained and changed by an ecology of games'. Networks emerge and continue to exist because actors are dependent on each other. Actors cannot achieve their objectives without resources which are possessed by other actors. Thus, networks are characterized by a limited substitutability of resources, which ensures that
Erik-Hans Klijn is in the Department of Public

Administration, Erasmus University Rotterdam.

Geert R. Teisman is Professor in the Department of Public

Administration, Erasmus University Rotterdam. 
sustainable social relations are created between actors.

Within these policy networks, actors conduct themselves strategically in policy processes. This theoretical framework sees policy processes as a series of games (see Scharpf, 1997 for an explanation of the game concept). The multiplicity of actors and their various (and often conflicting) perceptions, interests and strategies, make these games complex (see, for example, Teisman, 2000).

Games are played in arenas_-some games are played out in several arenas at once (Klijn et al., 2000). Arenas are the action context in which the games take place. Arenas can be characterized by a specific set of actors, the decision-making situation in which they find themselves (constellation of preferences and positions), and the organizational arrangements according to which decisions are made. Arenas are 'activated game fields' and can be located within one or more networks. Some of the actors in a network will not be involved in all the games and arenas.

Games are likely to become complicated if they take place in arenas that are located in different networks - this makes it more difficult to connect the various interactions. Also, in these cases, it is more likely that different rules of behaviour will be needed (Klijn, 2001).

Actors, Networks, Arenas and Strategies

PPPs include actors from different networks, each with their own history and practices, and they are constantly influenced by decisions made in other arenas. A PPP is created by a game that involves more than one arena (for instance central and local government), and more than one network (for instance a traffic and transport network and a public housing network). At the same time, a game surrounding a PPP project can be influenced by decisions taken in other games and arenas.

In these games, each of the actors chooses their own strategy. This can make decisionmaking in PPPs extremely complex, because decisions are faced not only with an institutional complexity, but also with a strategic complexity.

\section{PPPs in Dutch Key Projects}

Projects in the Netherlands where it has been decided that PPP should play an important role are called 'key projects'. The concept of the key project is used by the Dutch Ministry of Housing, Planning and the Environment ('VROM') to define large-scale urban development projects which fit in with national policy. The aim of the key projects policy is to strengthen the economic structure, while at the same time improving environmental quality and providing a more effective use of space. There are presently six key projects on urban redevelopment in the Netherlands. They all involve large, existing office buildings, infrastructure and shopping and recreational services. Because the projects require an invasion into the existing urban infrastructure, a wide variety of actors is involved.

The plans were adopted by the Dutch government because they offer a high level of local improvement. In addition to employment and improved access, the government also wishes to realize a more intensive use of the existing urban space, as well as revitalizing social-economic activity (Kenniscentrum, 1999).

\section{Case Studies}

In this section, we identify some characteristics of the partnerships involved in three examples of these projects.

Case 1: The Utrecht Central Station (UCP) Project This project involves redeveloping the area around the railway station, including the Hoog Catharijne shopping centre in which the station is situated. It calls for the construction of $330,000 \mathrm{~m}^{2}$ of new offices, 1,750 apartments and $61,200 \mathrm{~m}^{2}$ of shops, in addition to some infrastructural developments intended to open up the centre. The number of barriers that restrict access to the Central Station, Hoog Catharijne, and Jaarbeurs Complex (a conference centre) is to be reduced. In addition, the project aims to improve public space, for instance through the construction of new public squares and the improvement of existing ones, reduce the amount of water present in the Catharijnesingel (Catharijne Canal), and improve the infrastructure for cars and bicycles. Another objective is to improve internal traffic facilities so that passengers have quick, efficient and easy travel using public transport and achieve good connections to other types of transport. Finally, the project aims to strengthen economic opportunities.

In the early 1980s, the Dutch government, the Dutch national railways (NS), the owners of the Jaarbeurs Complex, and the owner of the Hoog Catharijne shopping centre drew up plans to redevelop the area. A memorandum of understanding was published in 1988, when the four bodies agreed to develop a master plan for the area. Taking into account the differences of opinion between the municipality and the three landowners, a new initiative was launched-after realization of the master plan 
in 1993-which involved the creation of a development corporation owned by the municipality and by three large project developers. None of these project developers had any existing interests in the area, and when initiatives by this coalition were blocked by the three existing actors (the three landowners) in mid-1995, the development corporation effectively ceased functioning.

The municipality began co-operating with the landowners again in 1996 and in December 1997 this new venture presented a Definitive City Plan Design (DCPD). The municipal council tentatively approved this plan despite growing opposition organized by a new political party called 'Leefbaar Utrecht' (Liveable Utrecht). Agreements were made about investments in 'public space' on condition that the Dutch government would contribute. With the help of an urban architectural supervisor, and a specially created quality team, guarantees were built in to monitor progress.

In spring 2000, co-operation between the municipality and the private sector failed once more. The private sector participants withdrew because they felt that the investments they had to make in the public space were too high.

Shortly after this break-up, Leefbaar Utrecht won the election and obtained an important position in the local council. The party started to amend the plans, and in 2002 consulted the citizens on two new versions. In 2002, the version which incorporated certain 'green' qualities (more trees, restoration of canals) was accepted. Not only do several important issues regarding mobility and finance still need to be solved here, but we may also question the labelling of the project as a 'partnership'.

\section{Case 2: The Amsterdam South Axis}

The 'South Axis' project concerns the (re)development of the area surrounding the Amsterdam South/WTC railway station and the southern part of the motorway around Amsterdam. During the 1980s, there had been a rapid expansion of new office space in this area. One example is the new office of the large ABN-AMRO Bank. The City of Amsterdam had to make decisions on these expansions case by case, and in 1994 it wanted to develop more systematic planning for the area. For this purpose, the city managers set up the 'South Axis Coalition' in December 1994, in which all the prominent private actors took part. It was a kind of informal strategic group without any fixed membership. To support the coalition, a working group was set up consisting of civil servants from the main departments of the Amsterdam local administration in order to direct research toward possible solutions and start working on a master plan. A first draft of the plan was presented in October 1996. Sections of the master plan were discussed with interest groups in late 1996. As a result, additional housing (1,500 units) and other functions were added to the existing proposals. In 1997, the Real Estate department of the NS joined this strategic group, and the partners started working together on further development of the plan. They paid special attention to the idea of relocating transport infrastructure underground (motorway, heavy and light rail), in order to create possibilities above ground for the construction of new offices and housing.

This master plan was approved by the city council in January 1998. The area would be developed into a high-potential area of office space and private housing combined with transport facilities. The city initiated a number of fact-finding studies to explore the technical and financial possibilities of locating infrastructure below the first floor. Three important private actors, the ING Bank, the ABN-AMRO Bank and NS Real Estate, started to organize their strategies in a consortium. After some negotiations with the city, they guaranteed an investment of 2 billion Dutch Guilders (about 630M euro) in real estate above the tunnel containing the transport arteries, provided it was constructed and financed by the government. However, after long delays, no concrete results were obtained for the financing of the underground transport infrastructure. The enthusiastic co-operation between city managers and private actors began to stagnate.

Although agreements should have been signed by early 1999, in reality no agreement was reached on how to proceed further. The public-private co-operation structure began to unravel, and the focus shifted to the realization of real-estate projects that were not dependent on the new underground car and public transport infrastructure. The public managers once again took on a central role in the planning process. They reverted to negotiating on a bilateral basis with several private and public actors for commitments, money (from public actors) or partial investment projects (with private actors). Although the interaction between public and private actors remained intensive, their joint organization began to come apart, and responsibilities split up along traditional lines. 
In retrospect, the interaction that existed was used mainly for joint fact-finding, not for joint responsibility and joint decision-making. In terms of partnership, the Amsterdam South Axis is a good example of the type of cooperation that starts with high ambitions in terms of strategic alliances and joint decisionmaking, but in reality develops towards a network structure in which traditional roles are played and co-operation is based on bilateral agreements.

Case 3: Hoog Hage, the Central Station Project in The Hague

This project involves the restructuring of the area around the Central Station and was part of a large-scale inner-city renovation project started in the 1990s. In 1999, the decision was taken to develop first a small area (400 by 400 $\mathrm{m}^{2}$ ) around the station, which holds a large concentration of offices (mainly government departments and some cultural institutions such as the National Library and Museum of Literature). Each day, some 350,000 people use the train, metro or bus in and around the station. In 2002, growth was expected to reach $120,000 \mathrm{~m}^{2}$ of office space, $50,000 \mathrm{~m}^{2}$ of residential housing, $30,000 \mathrm{~m}^{2}$ for other functions, and 2,500 new parking spaces.

In the course of 1996, the main actors involved in the project set up an informal steering group to discuss initiatives for constructing plans for the area. This steering group commissioned a firm of architects to draw up the first draft of a master plan for the area. All the actors approved the draft of the master plan, which was presented in early 1997, and in June signed a covenant in which they agreed to carry out further research into the spatial and financial feasibility of the plan. The plan was also given key project status.

Although several actions were taken, including an unsuccessful attempt to set up a company to organize the joint financial contributions of public and private actors, no final plan had been realized by the end of 1998 . One of the actors, the Shell Pension Fund, which held an important site, opposed the plan. After intense discussion, the Pension Fund agreed at least to co-operate in the joint planning process until late 1999.

Commitment, however, had been somewhat eroded, and the local actors were waiting for a commitment from the central government. To speed up the development of the area around the station, in 1999 the City of The Hague decided to separate the core area around the station from the project and develop this area. It asked for financial support from the Dutch government. In July 2000, funds were granted from the key project budget. The city approved a project document outlining the programme for the area and the various facilities. The partners then began working on a new master plan for the area. The county government (Stadsgewest Haaglanden) had also become involved.

In early 2002, a draft master plan was presented to the city. The city and the NS, Multi Vastgoed and Babylon, which represented the shops and cinema next to the station, signed an agreement confirming their support of the master plan. The private actors were the first to develop a number of projects within the area. The master plan also regulated the phases of redevelopment and enforced arrangements regarding financing and organization of the project. The 2002 agreement can be viewed as an update of the 1997 agreement, but more solidly underpinned by financial obligations and organizational arrangements.

\section{Discussion}

The course of action taken in these three cases leads to a number of conclusions. First, regeneration processes are long and complex. This pattern can be seen in every intensivelyused urban area, especially around railway stations. This complexity has to do with the high amount of ambitions that have to be met in these areas. In Utrecht, the conflicts between economic and mobility needs and values of scale and quality of life were particularly intense and have actually changed the political landscape.

Public actors (mostly city governments) remain the key institutions which take the planning initiative and consult private actors on individual elements of the project. While more intensive or formalized forms of cooperation have been attempted-for instance in the early stages of the South Axis project (the strategy group) or the Utrecht Centre project (in the period 1998-2000)-they are shortlived. Partnerships are tempting due to the added value they can create but, in practice, a bilateral agreement is the most that bodies can deal with.

As a consequence, the concept of an integrated and combined investment programme is often converted into a set of loosely-linked projects. 'Synergy' and 'joint development' are nice words, but do not seem to be possible within the existing fragmented decision-making arenas. All bodies are far too 
preoccupied with their own procedures and internal issues to be able to act as partners.

\section{Actors and Interdependencies}

It is not easy to convert ambitions into actions in public administration. One problem is that implementation of the ambitions that are formulated at the national level have to be performed by local actors-municipalities, local interest groups, and private investors. Our cases were no exception.

We examined the roles of key players and peripheral actors in our case studies. Key players are formally involved in the process and/or interact on the substance and process of the project; they will have signed a formal agreement. Peripheral actors are those with an interest, but they are not systematically included in the interaction. They are part of the institutional context in which projects are embedded.

Key players have to consider the possibility that peripheral actors may intervene suddenly, or that the actions of these peripheral actors may have a substantial impact on the development of the area. One example is the UCP case, where opposition to the project resulted in the formation of a new political party, which played an important role. Peripheral actors, therefore, are not without power. Looking at key players and peripheral actors was especially informative about the perceived centrality of the policy arena surrounding the concept of key projects. Companies that want to settle in the area being developed are seen as peripheral actors, since they are only marginally involved in the debate on the key projects. In terms of the conceptual scheme presented earlier, they also operate in different arenas.

This complexity of actors and arenas is a feature of PPP projects. Time and again, adjacent arenas and policy games can be constructed that are equally central if we define the subject in a slightly different manner. If, for instance, we were to ask why the South Axis, the UCP or the Rotterdam Central Station offer development opportunities, the central arena would be the arena in which decision-making about the location is done by individual companies. Only a limited number of private actors, such as financiers and developers, possess the knowledge and means to engage in large projects. Opportunities for replacing public or private participants are limited (Scharpf, 1978). This makes actors mutually dependent. Even after a failure, as in the case of the UCP, cautious interactions begin again.
While this interdependency is the reason for the co-operation, it may also lead to inertia and blocking. Actors have little concern about sanctions for unco-operative behaviour, since they are indispensable to a large degree. Also, a kind of 'vendetta effect' may occur where actors, and especially the individual representatives of bodies, decide to settle old accounts and even out the cost of a previous project.

Finally, in regeneration projects, decisionmaking is dominated by real-estate bodies, while bodies responsible for infrastructure and logistics play a more peripheral role. However, the use of their investments and space is crucial to the success of the key projects.

\section{Interconnected Arenas and Networks}

The actors from the key projects contribute different means and play different roles. They also originate from different networks. In all of the Dutch key projects, decisions involve housing and environmental planning issues, as well as transport issues. The first of these is handled by the environmental network, in which the Ministry of Housing and Environmental Planning has a prominent role. Transport issues are dealt with by the transport network, where the Ministry of Transport has a prominent position. In both networks, various arenas are present in which the decisions are taken that are important to the key projects.

One example that figures prominently in all three cases is an arena within the transport network where decisions are taken about a light railway system between the cities of Amsterdam, Utrecht, The Hague and Rotterdam. Decisions taken in this arena (the 'BOR' arena) are important to the projects because they create possibilities (and set conditions and limitations) not just for better transport, but also for improvement of the stations in those areas. But most of the actors in the key projects do not participate in this arena. And in this way we can find many arenas where important decisions are taken. Each time the initiators and managers of the three key projects have to ask themselves: in which arenas can I participate and what compensation does this bring in return for the time it costs me? But connecting all these decisions is also very time-consuming and requires excellent management skills. Much can go wrong and does go wrong when trying to establish these connections.

\section{Separation: The Problem of Domains}

The fact that decisions in PPP projects have to 
be linked to various different actors, arenas and networks constitutes not only an organizational problem in terms of management, but also a domain problem. Rules that help to determine and demarcate land ownership, or rules that regulate interactions (such as providing information, conflict management, access etc.) can differ between networks, can conflict with one another, or can simply block interaction with actors from other networks (see Ostrom, 1986; Klijn, 2001). Thus there is a clear description of what falls under the competency of a ministry (although competency conflicts between ministries are frequent, so the rules are not entirely unambiguous). The lines of demarcation between different sector networks or departments may also cause problems for PPP projects.

However, strict demarcation lines between actors also act as barriers against cooperation, since actors are unwilling to relinquish their own domain or do not want to forge links with other actors, since this would not fit in with the pattern of their own domains which has developed over time. Hence, in the UCP-case, WBN believes that it is normal for existing investments in Hoog Catherijne (traditionally the domain of WBN) to be more important than the development of investments around the Jaarbeurs. As a consequence, WBN initially allowed talks about opening new shopping areas around the Jaarbeurs - on which basis the Jaarbeurs agreed to invest in the public space-but ultimately the WBN torpedoed these plans, claiming that the development of shops in the Jaarbeurs area fell under the domain of the WBN. The Jaarbeurs project was unable to continue after this and was forced to break off its co-operation with the municipality. In the Hoog Hage case, similar problems of domain demarcation can be seen.

In short, the institutional fragmentation of PPP projects can create enormous barriers. It enhances the complexity of decisionmaking and calls for a huge managerial effort.

\section{Institutional Roles and Strategic Behaviour}

Although actors do get together to undertake collective action in the beginning, often this action does not result in a collective outcome. Either actors hesitate to commit themselves to each other or-and sometimes both of these things happen-joint efforts and the integral character of projects become disconnected at a later stage. The outcome is a clearer separation of responsibilities in which each of the (mainly public and private) actors concentrates on their own task. This also results in a dominant pattern, in which the relationship is organized contractually, rather than as a partnership.

This article shows how difficult it is to change role conceptions and domain demarcations. Some authors believe that the division between public and private domain is impossible to solve, pointing out a difference in value patterns. Jacobs (1992, p. 32) describes the public and private domain as two ethical systems with different 'moral syndromes'. The public domain is characterized by the guardian syndrome, the private domain by the commercial syndrome. Typical of the guardian syndrome are values such as:

- Avoiding trade and commerce.

- Striving for discipline and loyalty.

- Respecting tradition and hierarchy.

There is also a certain degree of fatalism, linked to a strong devotion to the task at hand. The commercial syndrome is characterized by values such as:

-Avoiding violence.

- Achieving agreements on a voluntary basis.

- Honesty.

- Competitiveness.

Other values, such as optimism and appreciation of initiative, are also part of this syndrome. According to Jacobs there are two types of survival: tasks that belong to the state, and trading linked to the market system. The two moral syndromes each belong to a pattern of survival; they are survival systems and cannot be merged without a problem. In fact, you could say that they are mutually exclusive.

Other authors also doubt the survival rate of hybrid organizations or hybrid constructions. Simon (1990) translates this into a distinction between task and market organizations. A task organization receives an assignment from a principal, together with the means to fulfil that task. Simon's values are comparable to Jacobs' guardian syndrome:

- Obedience.

- The absence of a profit motive.

- Loyalty. 
Table 3. Relations between the core businesses, values and strategies of public and private actors.

\begin{tabular}{|c|c|c|c|}
\hline & Public actors & Private actors & Tension \\
\hline Core business & $\begin{array}{l}\text { Objectives: (sectoral) public objectives } \\
\text { Continuity: political conditions }\end{array}$ & $\begin{array}{l}\text { Objectives: realizing profits } \\
\text { Continuity: financial conditions }\end{array}$ & $\begin{array}{l}\text { Different problem definitions: } \\
\text { political risks in expectations } \\
\text { versus market risks } \\
\text { in annual figures }\end{array}$ \\
\hline Values & $\begin{array}{l}\text { Loyalty } \\
\text { Devoted to a self-defined public cause } \\
\text { Controllability of process and approach } \\
\text { (political/social) } \\
\text { Emphasis on risk avoidance and } \\
\text { preventing expectations }\end{array}$ & $\begin{array}{l}\text { Competitive } \\
\text { Devoted to consumer preferences } \\
\text { Controlled by shareholders on the } \\
\text { basis of results } \\
\text { Emphasis on market opportunities } \\
\text { and risks and innovations }\end{array}$ & $\begin{array}{l}\text { Government reluctant in process } \\
\text { versus private party reluctant with } \\
\text { knowledge } \\
\text { Government reluctant in result } \\
\text { versus private parties reluctant } \\
\text { with their own effort }\end{array}$ \\
\hline Strategies & $\begin{array}{l}\text { Search for ways to guarantee } \\
\text { substantive influence (primacy of the } \\
\text { public sector) } \\
\text { Minimizing expectations and insecurity } \\
\text { of implementation costs }\end{array}$ & $\begin{array}{l}\text { Search for certainties to produce } \\
\text { and/or obtain a contract } \\
\text { Minimizing political risks and } \\
\text { organizational costs as } \\
\text { a consequence of public 'viscosity' }\end{array}$ & $\begin{array}{l}\text { Confrontation leads to a mutual } \\
\text { locking-up' of agreements } \\
\text { 'and thus to tried and tested } \\
\text { types of co-operation (contracts) }\end{array}$ \\
\hline $\begin{array}{l}\text { Consequences } \\
\text { for PPP }\end{array}$ & $\begin{array}{l}\text { Emphasis on a limitation of risks } \\
\text { and on agreements that lead to } \\
\text { agreed procedures and public } \\
\text { sector dominance }\end{array}$ & $\begin{array}{l}\text { Emphasis on certainty of market } \\
\text { share and profit, which } \\
\text { leads to an expectant attitude } \\
\text { and limited investments until the } \\
\text { moment when the contract is } \\
\text { acquired }\end{array}$ & $\begin{array}{l}\text { The creation of added value through } \\
\text { cross-border interaction } \\
\text { is not realized }\end{array}$ \\
\hline
\end{tabular}

-An orientation towards continuity.

The market organization does not have a principal, but it does have clients. Such an organization is dominated by values which include:

- Respect for contracts.

- Appreciation of zeal and initiative.

These values are similar to the values of Jacobs' commercial syndrome. Simon assumes that mixed types between task and market organizations will not be stable and will evolve in a particular direction. Thus, a task organization that starts generating its own income and seeking clients will eventually evolve into a complete market organization.

\section{Strategies of Co-operation between Public and Private Bodies}

Although Jacobs' and Simon's views are somewhat extreme, they provide a basis for theorizing about public-private cooperation. They emphasise the need for coherence between organizational structures (to be designed) and organizational values (that dominate and can be only partially influenced). The inability to create new forms of coherence could explain why PPP is so difficult to realize and why attempts at cooperation often result in organizational divisions, while attempts at regulation result in contracting-out procedures and contracts.

Such procedures and contracts fit in with the value patterns of the organizations involved and demand the least amount of adaptation on the part of these organizations. Public actors generally feel that they are in control if a contracting-out approach is used, and thus run a limited risk. This fits in with their value patterns of hierarchy and the primacy of the public interest. They do not have to adapt their internal organization and can provide the political arena with a clear decision. Private actors run no more risks than they are accustomed to. They can 
work with a type of organization (contract) that is familiar to them and they can acquire the contract in a competitive effort.

Here we touch upon one of the core issues of PPP, which is that the values of public bodies will result in strategies aimed at controlling the substance of projects and minimizing financial risks. Public bodies do not mind spending money, even if it generates few returns. But public opinion has to be taken into account if there are expectations of costs and benefits, which subsequently fail to be realized. A recent example is the auction of the UMTS frequency bands. Because expectations were raised through foreign auctions, the Dutch Cabinet was severely criticised for disappointing returns, even though in the past the government gave away these types of services almost free and no one was bothered by it. In such cases, political accountability is without mercy. Thus, the management of the public's expectations is an important task when engaging in PPP.

The values of private actors lead to strategies where the certainty of obtaining a market share and profits are central, but where there is also an emphasis on seizing opportunity. However, there is an important difference in the public sector. A government can tolerate losses as long as they are accepted by its political and public electoral support base. Private enterprises are judged by results and therefore cannot hide behind symbolism. For them, it is the market mechanism that is without mercy.

As long as no contract is awarded, private actors wait. To put it somewhat more cynically, we could say that they have learned that government would rather do nothing than do something innovative (and thus potentially risky). Private bodies have also learned that it is better for them to provide standard solutions at reliable profits rather than present new (improved) solutions which may lead to unrest. A good example is the corrugated asphalt on highways-developed some time ago - which is safer when it rains, but more slippery when it is icy. The media made a substantial fuss about this, which resulted in a political risk.

\section{PPP: The Right Form at the Wrong Moment?}

We have found that the explanation for the inability to develop partnerships lies in a combination of three factors:
- Complexity of actor composition.

- Institutional factors.

- The strategic choices of public and private actors.

A contractual division of responsibilities, on the other hand, takes into account the existing institutional fragmentation (both between the public and private spheres as well as within each of them) and is a familiar, tried and tested form to manage public-private relationships. And splitting the project up in sections reduces the complexity of the decision-making process. Furthermore, contracts reduce risks and act as a guarantee against opportunism (Williamson, 1996).

This is reflected in public actors wanting to minimize expectations and implementation costs while securing a political influence on the projects. Private actors look for certainties in order to minimize political risks. Together they produce a situation in which they focus on a separation of responsibilities and emphasise contractual relations.

This effect unfortunately works against projects which require innovation and the development of high-quality products. Also, the realization of products and services of an integral nature is rarely accomplished. Here, strong tension is visible between the explicit wishes of actors and views on the necessity of integrated high-quality products and services in a network society on the one hand, and the existing institutional structures and chosen strategies of actors on the other hand (Kenniscentrum, 1998, 1999; SER, 1999).

Perhaps PPP is a logical arrangement that will find its place in a network society where knowledge and resources are distributed over various actors. Such a new society, however, does not exist. PPP is simply an example of the right proposal at the wrong time. Real partnerships do not (yet?) fit in with the institutional rules, roles and habits based on a public-private division at the beginning of the 21 st century.

\section{References}

Alter, C. and Hage, J. (1993), Organizations Working Together (Sage, London).

Castells, M. (2000, The Rise of the Network Society: Economy, Society and Culture (Blackwell Publishers, Oxford).

Emerson, R. M. (1962), Power-dependency relations. American Sociological Review, 27, pp. 31-40. 
Falconer, P. K. and McLaughlin, K. (2000), Public-private partnerships and the 'New Labour' government in Britain. In Osborne, $\mathrm{S}$. P. (Ed), Public-Private Partnerships (Routledge, London).

Jacobs, J. (1992), Systems of Survival (Random House, London).

Kenniscentrum [Knowledge Centre] (1998), Final report on Added Value through Co-operation (The Hague).

Kenniscentrum [Knowledge Centre] (1999), PPP Progress Report (The Hague).

Kickert, W. J. M., Klijn, E. H. and Koppenjan, J. F. M. (1997), Managing Complex Networks: Strategies for the Public Sector (Sage, London).

Klijn, E. H. and Koppenjan, J. F. M. (2000), Public management and policy networks: Foundations of a network approach to governance. Public Management, 2, 2 (pp. 135158).

Klijn, E. H., van Bueren, E. and Koppenjan, J. F. M. (2000), Spelen met onzekerheid; over diffuse besluitvorming in beleidsnetwerken en mogelijkheden voor management [Playing with uncertainty; on diffuse decision-making in policy networks and possibilities for management], (Eburon, Delft).

Klijn, E. H. and Teisman, G. R. (2000), Governing public-private partnerships: Analysing and managing the processes and institutional characteristics of public-private partnerships. In Osborne, S. P. (Ed), Public-Private Partnerships (Routledge, London).

Klijn, E. H. (2001), Rules as institutional context for decision making in networks: The approach to post-war housing districts in two cities. Administration and Society, 33, 3, pp. 133-164.

Ministry of Finance (1998), Final Report of the MDW Working Party on Market and Government (The Hague).

Osborne, S. P. (Ed), (2000), Public-Private Partnerships (Routledge, London).
Ostrom, E. (1986), A method for institutional analysis. In Kaufman, F. X., Majone, G. and Ostrom, V. (Eds), Guidance, Control and Evaluation in the Public Sector: The Bielefeld Interdisciplinary Project (Walter de Gruyter, Berlin).

Rogers, D. L. and Whetten, D. A. (1982), Interorganizational Coordination: Theory, Research and Implementation (Iowa State University Press).

Scharpf, F. W. (1978), Interorganizational policy studies: Issues, concepts and perspectives. In Hanf, K. and Scharpf, F. W. (Eds), (1978), Interorganizational Policy-Making (Sage, London).

Scharpf, F. W. (1997), Games Real Actors Play (Westview Press, Boulder).

SER (1999), Startnota Ruimtelijke Ordening en de Perspectieven Nota Verkeer en Vervoer [Initial memorandum on spatial planning and the perspectives of the traffic and transport memorandum], (SDU, The Hague).

Simon, M, (1990), De Strategische Functietypologie [Strategic function typology], (SDU, The Hague).

Teisman, G. R. (1992/1995), Complexe besluitvorming; een pluricentrisch perspectief op besluitvorming over infrastructuren [Complex decision-making; a pluricentric view of decision-making on infrastructural investments] (Vuga, Den Haag).

Teisman, G. R. (1997), Sturen via creatieve concurrentie [Governance through creative competition], (Catholic University of Nijmegen, Nijmegen).

Teisman G. R. (2000), Models for research into decision-making processes. Public Administration, 78, 4, pp. 937-956.

Williamson, O. E. (1996), The Mechanisms of Governance (Oxford University Press, Oxford). 